Article

\title{
Building Thermo-Modernisation Solution Based on the Multi-Objective Optimisation Method
}

\author{
Małgorzata Basińska ${ }^{1}$, Dobrosława Kaczorek ${ }^{2, *}$ and Halina Koczyk ${ }^{1}$ \\ 1 Institute of Environmental Engineering and Building Installations, Faculty of Environmental Engineering \\ and Energy, Poznań University of Technology, Berdychowo 4, 60-965 Poznań, Poland; \\ malgorzata.basinska@put.poznan.pl (M.B.); halina.koczyk@put.poznan.pl (H.K.) \\ 2 Thermal Physics, Acoustics and Environment Department, Building Research Institute (ITB), Filtrowa 1, \\ 00-611 Warsaw, Poland \\ * Correspondence: d.kaczorek@itb.pl
}

Received: 2 March 2020; Accepted: 16 March 2020; Published: 19 March 2020

check for updates

\begin{abstract}
This study presents a multi-objective optimisation of building thermo-modernisation for multi-family buildings. The applied model has considered alternative solutions for insulation materials, with different thicknesses and different types of windows. The weighted sum method was applied to find a solution considering the minimisation of global cost, primary energy ratio and $\mathrm{CO}_{2}$ emissions. The solutions were compared for a building equipped with natural ventilation, and with mechanical supply-exhaust ventilation. In reference to the two considered types of ventilation, we analysed how the modification of an insulation thickness, its type and the type of installed windows, can be converted into individual evaluation criteria. The weights of the considered criteria were changed; however, this had no influence on the optimal solution. If the aim is to achieve the standards of zero-energy buildings, natural ventilation cannot be applied, despite the high value of thermal insulation of the building envelopes. Alternative solutions exist for buildings with natural ventilation and mechanical ventilation with heat recovery, where the primary energy ratio is the same for both, but the global costs are different. The additional energy and environmental input for the production of materials and elements to be replaced are insignificant in comparison to the savings brought about by thermo-modernisation.
\end{abstract}

Keywords: global cost methodology; multi-objective optimisation; primary energy; thermo-modernisation

\section{Introduction}

As almost $50 \%$ of the final energy consumed in the EU is allocated to heating and cooling, and $80 \%$ of that falls on buildings, the construction sector has become an important target in terms of reducing carbon dioxide emissions and energy consumption, as well as resource consumption. Many current energy-related policies focus on new buildings, but in most countries the majority of the existing building stock has low energy performance. Therefore, the new Energy Performance of Buildings Directive (EPBD) 2018/ 844 [1] deals primarily with the problem of energy consumption in existing buildings and defines the requirements for their cost-effective energy renovation. These buildings should become almost zero-energy buildings (nZEBs). Nearly zero-energy buildings are defined as buildings with very high energy efficiency, where energy demand should be mostly covered by renewable sources of energy. Achieving the nZEB standard for new buildings is much easier compared to the energy renovation of old, existing buildings. The classic approach to the renovation of existing buildings, i.e. limited to individual, selected building elements, without analysing the problem as a whole, will not lead to the selection of the optimal solution. Many variables with a wide range of values have to be considered and, generally, the solution must not only fulfil the requirements in terms 
of the energy efficiency of the building envelope and systems but also pursue goals of environmental sustainability and economic feasibility [2]. In this spirit, as part of the Horizon 2020 program entitled "Decarbonising construction resources in the EU - innovative approaches and inexpensive solutions changing the building renovation market", projects are underway to develop innovative and affordable solutions for decarbonising buildings in the EU, accelerating the renovation of buildings throughout Europe. A good example can be the DRIVE 0 project [3] that offers efficient solutions for energy, materials and costs as a part of innovative consumer-oriented circular renovation processes, or the STEP UP project [4], which will deliver plug and play technologies for minimal disruption, interconnected for maximum impact on energy, costs, indoor air quality and user comfort. The designer should take into account the best combination of these parameters to determine an optimal design solution or set of solutions from a wide range of feasible options, according to the objective and restriction functions defined $[5,6]$. In recent years, there has been a growing interest in both the scientific and industrial sectors for the multi-objective optimisation (MOO) process. The most recent research in the subject of optimum solutions to complex problems of energy efficiency in buildings is summarised in Ascione et al. [7]. Despite the large number of presented studies on optimising energy consumption, this review hardly contains studies on the renovation of existing residential buildings considering both energy and environmental assessments. The following is a review of the recent, selected work on residential building energy renovation optimisation presenting several methods, optimisation approaches and various design variables and goal functions.

\subsection{Literature Review}

The most frequently defined objective functions in optimisation analysis are the energy and retrofit cost. The objective functions associated with energy are mostly expressed as minimising energy consumption, energy demand and energy load, and maximising savings. In turn, the objective functions associated with the retrofit cost are generally expressed as Net Present Value (NPV) or life cycle cost (LCC) analysis.

In Bolattürk's [8] research, the determination of the optimal thickness of insulation on the external walls of buildings is analysed comparatively based on annual heating and cooling loads, using the life cycle cost economic factor as an objective function. Flores-Colen and Brito [9] characterised a systematic methodology for selecting optimal maintenance strategies for façades based on various maintenance principles and user interactions. They used the LCC analysis to compare different maintenance scenarios using the equivalent uniform annual cost (EUAC) for five façade claddings. Gasparell et al. [10] evaluated the impact of different kinds of glazing systems (two double and two triple glazing), window size, orientation of the main windowed façade and internal gains on winter and summer energy needs, and peak loads of a well-insulated residential building in four localities of central and southern Europe. Ruiz and Romero [11] in Spain and Yu and al. [12] in China studied the effects of different types of glazing systems, window orientation and wall insulation from an energetic point of view.

The examples cited above relate to simple objective optimisation. Many authors use more advanced models, such as MOO models. A MOO model enables to consider a large set of building retrofit options, implicitly defined by the constraints of the search space and highlighting the trade-offs between the objective functions in order to reach a satisfactory compromise solution [13]. Basińska [14] used the weighted sum model (WSM) to optimise the building envelope and technical equipment, assuming the following criteria: economic, energy-related and environmental. The same WSM model for converting a multi-objective problem to a single-objective one was implemented by Fan and Xia [15]. They used the multi-objective model for retrofitting a building envelope to maximise energy savings and reap economic benefits.

Nowadays, in addition to traditional multi-objective optimisation methods, such as WSM, evolutionary algorithms are also used. The non-dominated and crowding distance sorting genetic algorithm (NSGA-II) $[16,17]$ is recognised as one of the most efficient multi-objective evolutionary 
algorithms (MOEA) in the research of the built environment when dealing with a potentially large number of solutions. Li et al. [18] analysed the behaviour of four different MOO algorithms: the NSGA-II, the multi-purpose particle swarm optimisation (MOPSO), the multi-purpose genetic algorithm (MOGA) and the multi-purpose differential evolution (MODE), in solving design problems regarding building performance.

In the study conducted by Abdallah and El-Rayes [19], a novel optimisation model that provides the capability of optimising building upgrade decisions in order to minimise their negative environmental impact while complying with a set upgrade budget and owner-specified building operational performance was developed. In this study, the NSGA-II method was applied to optimise the parameters connected with lighting and heating, ventilation and air-conditioning (HVAC) systems. Yang et al. [20] used genetic algorithms (GA) to find the optimal size and characteristics of glass surfaces and building shading devices in order to minimise the energy demand of case study buildings. Penna et al. [21] examined the possibility of using optimisation methods for renovating buildings in order to achieve nZEB energy performance. An artificial intelligence system for the prediction of the energy performance of residential buildings has been proposed by Castelli et al. [22].

Palonen et al. [23] presented GA for the optimisation of detached building envelopes and HVAC system parameters, where the investment cost of insulation and windows was used as an objective function. In [24], the Pareto front concept was applied and bi-objective optimisation was implemented by running the modified GA in order to identify low-emission cost-effective design solutions for a single-family dwelling in the cold climate of Helsinki, Finland. Moreover, Brunelli et al. [25] employed the GA for achieving sustainable design by setting five objectives: minimisation of thermal energy demand, electric energy consumption, $\mathrm{CO}_{2}$-eq emissions, maximisation of investment net present value (NPV) and thermal comfort.

In turn, Schwartz et al. [26] used MOGA in order to find optimal designs for the refurbishment of a residential complex case study, in terms of life cycle carbon footprint (LCCF) and LCC. Sharif et al. [27] created a solid artificial neural network (ANN) to test extensive and complex data generated from the simulation-based multiple-goal optimisation model. The proposed model was used to predict the total energy consumption (TEC), LCC and life cycle assessment (LCA) for various renovation scenarios, ultimately choosing the optimal scenario.

Researchers, such as Grygierek and Ferdyn-Grygierek [28], have linked energy and thermal comfort as objective functions. The authors tested the influence of four types of windows, building orientation, external walls, roof, ground floor insulation and infiltration on LCC and thermal comfort for a single-family building. Yu et al. [17] optimised the energy consumption of a building, maximising the thermal comfort of its occupants. Additionally, Bre et al. [29] focused on the properties of the building envelope for ameliorating energy efficiency and thermal comfort in dwellings. They developed and validated a computational code for the multi-objective optimisation of a building's thermal performance, considering several design variables, e.g., the kind of roof slabs and walls, the solar absorbance of coating and shading.

The studies cited above show different approaches to building energy optimisation. The objective function can refer to energy, environmental, economic and comfort parameters. The design variables can refer to the envelope and the technical equipment of the building. The number of combinations of the above parameters, which are determined by the researcher each time, gives great opportunities for analysis. Nevertheless, the above literature review shows that there is still a lack of analyses of basic modernisation measures aimed at reducing the building's energy consumption in the Central European countries belonging to the V4 group. In addition, none of the above analyses presents alternative solutions in the field of insulation and windows in relation to a building with natural and mechanical ventilation, taking into account economic, environmental and energy criteria 


\subsection{Aim of the Study}

A wide range of technologies to increase energy savings has become available during the past decade but the most popular measures refer to improving the thermal insulation of the building envelope and windows replacement. The assessment of the impact of such technology measures on building energy performance requires the implementation of the most appropriate technologies.

This study presents multi-objective optimisation for the selection of building thermo-modernisation solutions for multi-family residential buildings located in the Polish climate zone in Poznan city. The applied model of multi-objective optimisation investigates alternative solutions for the thermo-modernisation of a building's envelope, in terms of the application of different insulation materials with different thicknesses, and different types of windows. The weighted sum method was applied in order to find a solution considering the minimisation of: global cost, primary energy index and $\mathrm{CO}_{2}$ emissions. The solutions were compared for the same building and analysed in two variants: first, as a building equipped with natural ventilation (BSC-A) and second as a building equipped with mechanical supply-exhaust ventilation (BSC-B). The proposed method was used for the evaluation of thermo-modernisation operations related to the building's envelope in relation to the recommendations regarding the thermal protection of buildings valid in Poland, and for indicating the alternative solutions for BSC-A and BSC-B variants taking into account as criteria the two considered ventilation types, insulation materials and the type of installed windows.

The paper is divided into the following parts: Section 2 presents the multi-objective optimisation model and describes the applied evaluation criteria and the assumed method of solution. Section 3 describes the analysed building and the list of analysed variants (the decision variables). The results of the calculations conducted according to the model presented in Section 2 are presented in Section 4, along with the processes to choose the optimal solution.

\section{Methodology}

\subsection{Multi-Objective Optimisation Problem}

This study considers the multi-objective optimisation of thermo-modernisation strategies. Therefore, it requires the definition of decision variables, objectives functions, criteria and, finally, the selection of a solution method.

\subsection{Objective Function-Criteria of Assessment}

\subsubsection{Primary Energy}

The general procedure for estimating the energy function was based on the primary energy calculation, according to PN EN ISO 13790 [30]. The primary energy ratio was determined for each variant of the thermo-modernisation solution, and defined as an annual energy usage of the energy calculated for the building's net heated area, $\left(\mathrm{A}_{\mathrm{f}}\right)$. This indicator includes the final energy value at the balance boundary of the building and the disbursals of non-renewable primary energy for the delivery of the used energy to the boundary of the object. The value of primary energy includes the needs of heating, ventilation and domestic hot water preparation. Cooling options were not included in the analyses.

The overall primary energy consumption is calculated on an annual basis using the climate data for Poznań city. The energy demand in winter is calculated as energy losses for the building envelope and ventilation minus the internal gains and solar gains, including a gain utilisation factor. The analyses were made assuming statistical, monthly variability of climate data [31]. The calculation of energy consumption for each end-use service and each energy carrier took into account the seasonal efficiency of generation, storage, distribution and emission. A previous article [32] presents the calculation scheme. 


\subsubsection{Life Cycle Assessment}

Life cycle assessment (LCA) was implemented as the environmental function, but only the reduction of $\mathrm{CO}_{2}$ emission factor (embodied carbon, operational carbon) was used to assess the environmental efficiency of selected retrofit strategies with respect to materials and operational energy use.

According to [33], the building life cycle includes successively related phases: the product stage (A1-3), the construction phase (A4-5), the use phase (B1-7) and the end-of-life phase (C1-4). Despite these standardisations, however, there are very few studies that have assessed all life cycle stages [34]. This is mainly due to the lack of information and the relatively low impact of each of these phases in comparison to the entire life cycle. The results from the analysis of the retrofit strategies conducted by [35] show the relatively minor importance of the transport stage, the construction process stage and the end-of-life stage vis-à-vis the environmental importance of the entire life cycle of the building. Therefore, in this study, the system boundaries include the product, replacement and use stage phases in the framework of $\mathrm{CO}_{2}$ emission analyses.

The functional equivalent used to compare the different renovation strategies is the building itself and the results are expressed per year and per unit of net heated area. The reference service life of a building is assumed to be 50 years. The estimated service life for windows and insulations is established to be 30 years.

The initial embodied carbon values associated with the production phase, from the level of raw materials to building materials has been calculated using process data from Ecoinvent [36] databases and the environmental product declaration (EPD) [37-41]. As construction materials, such as insulation and windows, do not have the same estimated useful life as the building's reference lifetime, recurrent values for embodied carbon required for manufacture and refurbishment materials have been included in the calculations.

\subsubsection{Global Cost}

The global cost of building components is calculated as a sum of the initial investment costs and the discounted annual operating costs during the calculation period minus the residual value of each of the components in respect to the initial year. It includes energy, maintenance and operational costs. The calculations are consistent with the cost-optimal methodology established in directive on the energy performance of buildings (Directive 2010/31/EU) [42]. The analysis by means of the global cost method was performed using Equation (1) [43]:

$$
C_{G(\tau)}=C_{i n, i n v}+\sum_{j=1}^{j_{x}}\left[\sum_{i=1}^{\tau}\left(C_{a, i}(j) \cdot R_{d}(i)\right)-V_{f, \tau}(j)\right]
$$

where $C_{G}(\tau)$ is the global cost referring to the starting year, PLN; $C_{i n, i n v}$ is the initial investment costs, PLN; $j$ is the index of component or system; $j_{x}$ is the number of components or systems; $\tau$ is the calculation period, $a ; C_{a, i}(j)$ is the annual costs for component or system $j$ of year $i$, PLN; $R_{d}(i)$ is the discount rate (for year $i$ ); $V_{f}, \tau(j)$ is the final value of component or system $j$ (corresponding to calculation period $\tau$ ), PLN.

The value of money in time $R_{d}(i)$ takes into account the annual inflation rate $\left(R_{i}\right)$ and the Warsaw Interbank Offered Rate (WIBOR). Energy costs represent the costs of energy consumption and fixed fees for its willingness to provide energy. Equation (2) represents the final value of component corresponding to calculation period $\tau$ :

$$
V_{f, \tau}(j)=C_{i n v}(j) \cdot\left(1+\frac{R_{p}}{100}\right)^{n_{\tau}(j) \cdot \tau_{n}(j)} \cdot\left(\frac{n_{\tau}(j) \cdot \tau_{n}(j)-\tau}{\tau_{n}(j)}\right) \cdot R_{d}(\tau)
$$


where $C_{i n v}$ is the investment cost, PLN; $n_{\tau}(j)$ is the total number of replacements of components $j$ throughout the calculation period; $R_{d}(\tau)$ is the discount rate at the end of the calculation period. The analyses include the values of macro-economic parameters, which are constant over time (Table 1). An analysis of the sensitivity of the global cost method to the variability of macroeconomic parameters is presented in an article by Basińska et al. [31]. The initial costs of investment were assumed based on the analysis of the consumer market costs.

Table 1. Macro-economic parameters.

\begin{tabular}{cccc}
\hline & Inflation & WIBOR & Discount Rate \\
\hline$[\%]$ & 2.5 & 4.7 & 2.15 \\
\hline
\end{tabular}

\subsection{Objective Function Calculation Procedures [14]}

The multi-objective optimisation model was solved by the WSM method. The WSM method is a basic and easy-to-use approach that gives an acceptable approximation of one's preference function when the preference information is not too complex. In this method, the chosen solution from all the available solutions is a compromise between the objective functions: the criteria $C_{r}(r=4)$, which are: $\mathrm{C}_{1}$-primary energy $\left(\mathrm{PE}_{\mathrm{H}+\mathrm{W}}\right), \mathrm{C}_{2}$ - global cost $\left(\mathrm{C}_{\mathrm{G}}\right), \mathrm{C}_{3}-\mathrm{LCA}$ (expressed by decrease in $\mathrm{CO}_{2}$ emissions) and $\mathrm{C}_{4}$-global cost increase $\left(\Delta \mathrm{C}_{\mathrm{G}}\right)$, (Equation (3)):

$$
\text { Maximum : } F=\rightarrow \mathbf{f}(\rightarrow \mathbf{y})=\left[\mathrm{f}_{1}(\rightarrow \mathbf{y}), \mathrm{f}_{2}(\rightarrow \mathbf{y}), \mathrm{f}_{3}(\rightarrow \mathbf{y}), \mathrm{f}_{4}(\rightarrow \mathbf{y})\right]
$$

In order to normalise the objective function, the inhibitor was applied to the variant matrix, which means that the lower the value of a given function, the higher the grade achieved by the given variant. In order to determine the optimal solution, the aggregate $y$ variant indicator was used.

$$
\mathbf{y}=\rightarrow \mathbf{f}\left(\rightarrow \mathbf{X}, \mathrm{w}_{\mathrm{ht}}\right)=\left[\mathrm{f}_{1}\left(\rightarrow \mathbf{X}, \mathrm{w}_{\mathrm{ht}}\right), \mathrm{f}_{2}\left(\rightarrow \mathbf{X}, \mathrm{w}_{\mathrm{ht}}\right), \mathrm{f}_{3}\left(\rightarrow \mathbf{X}, \mathrm{w}_{\mathrm{ht}}\right), \mathrm{f}_{4}\left(\rightarrow \mathbf{X}, \mathrm{w}_{\mathrm{ht}}\right)\right]
$$

where $\rightarrow \mathbf{y}$ is the vector of variant's aggregated indicator $\rightarrow \mathbf{x} ; \mathbf{w}_{\mathrm{ht}}$ is the criterion weight; $\rightarrow \mathbf{X}$ is the vector of the normalised value of the $C$ criterion for the variant $\rightarrow \mathbf{x}$ according to Equation (4):

$$
\mathbf{X}=\rightarrow \mathbf{f}(\rightarrow \mathbf{x})=\left[\mathbf{f}_{1}(\rightarrow \mathbf{x}), \mathbf{f}_{2}(\rightarrow \mathbf{x}), \mathbf{f}_{3}(\rightarrow \mathbf{x}), \mathbf{f}_{4}(\rightarrow \mathbf{x})\right]
$$

within each of the criteria, the optimisation problem was to minimise the final value as described below:

$$
\begin{gathered}
\text { Minimise }: \mathrm{C}=\rightarrow \mathrm{f}(\rightarrow \mathrm{x}) \\
\mathbf{x}=\left[x_{1}, \ldots, x_{n}\right]
\end{gathered}
$$

where $\rightarrow \mathbf{x}$ is a vector of $\mathbf{n}$ decision variables.

Each element of vector $\rightarrow \mathbf{x}$ corresponds to a decision variable, i.e., it defines the costs and relevant technical parameters associated with a given variant. Variant $\rightarrow \mathrm{x}$ is a combination of variable actions on the building envelope side.

\section{Case Study}

\subsection{Characteristics of Building}

The building studied is a multi-family building (Figure 1), constructed in 2002, situated in Poznań in Poland. The object has four levels: one staircase and one basement under the entire building. It is covered by a ventilated roof. It consists of 16 apartments (four apartments on each level with an area from $39.4 \mathrm{~m}^{2}$ to $51.7 \mathrm{~m}^{2}$ ), with a total area of $753.8 \mathrm{~m}^{2}$. The building's net heated area is $\mathrm{A}_{\mathrm{f}}=898.4 \mathrm{~m}^{2}$, including the apartments and staircase. The external walls are made from two layers 
of chequer bricks $25 \mathrm{~cm}$ thick with a layer of $12 \mathrm{~cm}$ of thermal insulation with the resulting thermal transmittance $\mathrm{U}_{\mathrm{ex}}=0.55 \mathrm{~W} /\left(\mathrm{m}^{2} \cdot \mathrm{K}\right)$. The windows are made of polyvinyl chloride (PVC) with double glazing and thermal transmittance equal to $\mathrm{U}_{\mathrm{W}}=1.6 \mathrm{~W} /\left(\mathrm{m}^{2} \cdot \mathrm{K}\right)$. The thermal transmittance for the slab above the basement is $U_{b}=0.3 \mathrm{~W} /\left(\mathrm{m}^{2} \cdot \mathrm{K}\right)$ and for the roof $\mathrm{U}_{\mathrm{c}}=0.3 \mathrm{~W} /\left(\mathrm{m}^{2} \cdot \mathrm{K}\right)$. The analysis has been conducted for two variants of the ventilation system solutions-BSC-A with natural ventilation, assuming constant air exchange rate $\mathrm{ACH}=0.5 \mathrm{~h}^{-1}$, and BSC-B with mechanical supply-exhaust ventilation-with an assumed heat recovery efficiency of $60 \%$, assuming the outdoor air flow rate is equal to $120 \mathrm{~m}^{3} /$ (h-apartment), depending on the type of rooms in the apartment.

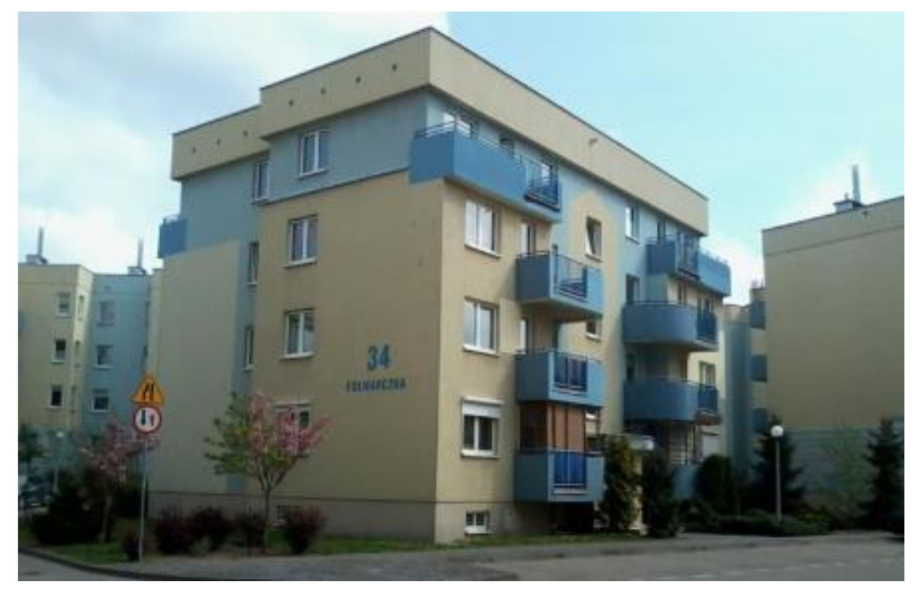

Figure 1. The analysed multi-family building.

\subsection{The Analysed Variants—Decision Variables}

The proposed multi-objective analysis takes into account the choice of optimal solution for each variant of the BSC-A or BSC-B buildings. The optimal variant is a combination of the variable performance for the building's envelope related to the choice of an insulation material-three variants (Table 2), insulation thickness-12 variants (Table 3) and the type of windows-six variants (Table 4). Altogether, this gives 216 combinations for each of the analysed building's variants. Additionally, Table 5 presents the assumed values of efficiency in the calculations of final energy (generation, storage, distribution and emission) and the heat recovery assumed for the supply-the exhaust ventilation for both variants of the analysed BSC-A and BSC-B buildings.

Table 2. Analysed variants of wall insulation materials.

\begin{tabular}{cccc}
\hline Variant & EPS & MW & XPS \\
\hline$\lambda,[\mathrm{W} /(\mathrm{m} \cdot \mathrm{K})]$ & 0.031 & 0.039 & 0.033 \\
\hline
\end{tabular}

Table 3. Analysed variants of insulation thickness with the $U_{e x}$ value $\left[\mathrm{W} /\left(\mathrm{m}^{2} \cdot \mathrm{K}\right)\right]$ for the variants.

\begin{tabular}{|c|c|c|c|c|c|c|c|c|c|c|c|c|}
\hline$[\mathrm{cm}]$ & +5 & +10 & +12 & +14 & +16 & +18 & +20 & +22 & +24 & +26 & +28 & +30 \\
\hline EPS & I-1 & $\mathrm{I}-2$ & $\mathrm{I}-3$ & $\mathrm{I}-4$ & I-5 & I-6 & $\mathrm{I}-7$ & $\mathrm{I}-8$ & I-9 & I-10 & I-11 & I-12 \\
\hline $\mathrm{U}_{\mathrm{ex}}$ & 0.29 & 0.20 & 0.18 & 0.16 & 0.14 & 0.13 & 0.12 & 0.11 & 0.11 & 0.10 & 0.09 & 0.08 \\
\hline MW & Ia-1 & Ia-2 & Ia-3 & Ia-4 & Ia-5 & Ia-6 & Ia-7 & Ia-8 & Ia-9 & Ia-10 & Ia-11 & Ia-12 \\
\hline $\mathrm{U}_{\mathrm{ex}}$ & 0.32 & 0.23 & 0.20 & 0.19 & 0.17 & 0.15 & 0.14 & 0.13 & 0.12 & 0.12 & 0.11 & 0.11 \\
\hline XPS & Ib-1 & Ib-2 & Ib-3 & Ib-4 & Ib-5 & Ib-6 & Ib-7 & Ib-8 & Ib-9 & Ib-10 & Ib-11 & Ib-12 \\
\hline $\mathrm{U}_{\mathrm{ex}}$ & 0.300 & 0.21 & 0.18 & 0.16 & 0.15 & 0.14 & 0.13 & 0.12 & 0.11 & 0.10 & 0.10 & 0.09 \\
\hline
\end{tabular}


Table 4. Analysed variants of windows.

\begin{tabular}{ccccccc}
\hline Variant & W-1 & W-2 & W-3 & W-4 & W-5 & W-6 \\
\hline $\mathrm{U}_{\mathrm{w}}\left[\mathrm{W} /\left(\mathrm{m}^{2} \cdot \mathrm{K}\right)\right]$ & 1.391 & 1.352 & 1.321 & 1.018 & 0.979 & 0.964 \\
$\mathrm{U}_{\mathrm{g}}\left[\mathrm{W} /\left(\mathrm{m}^{2} \cdot \mathrm{K}\right)\right]$ & 1.1 & 1.1 & 1.1 & 0.6 & 0.6 & 0.6 \\
$\mathrm{PVC}$ frame $\left[\mathrm{W} /\left(\mathrm{m}^{2} \cdot \mathrm{K}\right)\right]$ & - & 1.6 & - & - & 1.6 & - \\
wood frame $\left[\mathrm{W} /\left(\mathrm{m}^{2} \cdot \mathrm{K}\right)\right]$ & - & - & 1.5 & - & - & 1.5 \\
aluminium frame $\left[\mathrm{W} /\left(\mathrm{m}^{2} \cdot \mathrm{K}\right)\right]$ & 1.6 & - & - & 1.6 & - & - \\
spacer frame $[\mathrm{W} /(\mathrm{m} \cdot \mathrm{K})]$ & 0.063 & 0.048 & 0.046 & 0.063 & 0.048 & 0.052 \\
\hline
\end{tabular}

Table 5. Efficiency [-] and heat recovery [\%] for BSC-A and BSC-B variants.

\begin{tabular}{|c|c|c|c|c|c|c|c|c|c|c|c|c|}
\hline Variant & I-1 & I-2 & I-3 & I-4 & I-5 & I-6 & I-7 & I-8 & I-9 & I-10 & I-11 & I-12 \\
\hline & Ia-1 & Ia-2 & Ia-3 & Ia-4 & Ia-5 & Ia-6 & Ia-7 & Ia-8 & Ia-9 & Ia-10 & Ia-11 & Ia-12 \\
\hline & Ib-1 & Ib-2 & Ib-3 & Ib-4 & Ib-5 & Ib-6 & Ib-7 & Ib-8 & Ib-9 & Ib-10 & Ib-11 & Ib-12 \\
\hline \multicolumn{13}{|c|}{ BSC-A } \\
\hline$\eta_{\mathrm{H}, \mathrm{e}}$ & 0.77 & 0.82 & 0.82 & 0.88 & 0.88 & 0.88 & 0.89 & 0.89 & 0.89 & 0.93 & 0.93 & 0.93 \\
\hline$\eta_{\mathrm{H}, \mathrm{d}}$ & 0.80 & 0.80 & 0.90 & 0.90 & 0.90 & 0.90 & 0.90 & 0.96 & 0.96 & 0.96 & 0.96 & 0.96 \\
\hline$\eta_{\mathrm{H}, \mathrm{s}}$ & 0.90 & 0.90 & 0.93 & 0.93 & 0.93 & 0.93 & 0.93 & 0.95 & 0.95 & 0.95 & 0.95 & 0.95 \\
\hline$\eta_{\mathrm{H}, \mathrm{g}}$ & 0.86 & 0.86 & 0.87 & 0.87 & 0.87 & 0.91 & 0.91 & 0.91 & 0.91 & 0.94 & 0.94 & 0.94 \\
\hline$\eta_{W, d}$ & 0.60 & 0.60 & 0.70 & 0.70 & 0.70 & 0.70 & 0.70 & 0.80 & 0.80 & 0.80 & 0.80 & 0.80 \\
\hline$\eta_{\mathrm{W}, \mathrm{s}}$ & 0.60 & 0.60 & 0.65 & 0.65 & 0.65 & 0.80 & 0.80 & 0.80 & 0.80 & 0.85 & 0.85 & 0.85 \\
\hline$\eta_{W, g}$ & 0.65 & 0.65 & 0.83 & 0.83 & 0.83 & 0.83 & 0.83 & 0.85 & 0.85 & 0.85 & 0.85 & 0.85 \\
\hline \multicolumn{13}{|c|}{ BSC-B } \\
\hline$\eta_{\mathrm{H}, \mathrm{d}}$ & 0.95 & 0.95 & 0.95 & 0.95 & 0.95 & 0.95 & 0.95 & 0.95 & 0.95 & 0.95 & 0.95 & 0.95 \\
\hline$\%$ & 70 & 70 & 80 & 80 & 80 & 85 & 85 & 85 & 90 & 90 & 90 & 90 \\
\hline
\end{tabular}

The number of combinations in the analyses is unlimited and each time it can be increased by adding the thermo-insulation materials or assuming the combinations of the different variants of the windows. The package of the solutions includes the description of the possible operations, which may improve the objective functions. The improvement of the objective value of one function can be achieved only by assuming the degradation of another. This means that the chosen solution implies a need for compromise.

\subsection{The Investment Costs}

The initial costs were divided into construction and mechanical ones-permanent and independent from the variant (buildings costs-1710 PLN $/ \mathrm{m}^{2}$, investment costs of installed equipment related to energy consumption-221 PLN $/ \mathrm{m}^{2}$ for the BSC-A building and from $335 \mathrm{PLN} / \mathrm{m}^{2}$ to $416 \mathrm{PLN} / \mathrm{m}^{2}$ for BSC-B (depending on heat recovery costs) and variables depending on the variant (construction investment costs affecting energy consumption-the window's and insulation's costs). The variables investment costs for the analysed variants in Tables 6 and 7 were presented. The values are referenced $A_{f}$.

Table 6. Costs of insulation thickness for analysed variants, PLN/ $/ \mathrm{m}^{2}$.

\begin{tabular}{ccccccccccccc}
\hline Variant & I-1 & I-2 & I-3 & I-4 & I-5 & I-6 & I-7 & I-8 & I-9 & I-10 & I-11 & I-12 \\
\hline EPS & 172 & 188 & 195 & 201 & 209 & 215 & 222 & 228 & 235 & 242 & 248 & 255 \\
MW & 236 & 268 & 279 & 289 & 301 & 312 & 322 & 333 & 344 & 355 & 365 & 376 \\
XPS & 191 & 228 & 242 & 256 & 271 & 285 & 299 & 315 & 331 & 342 & 357 & 372 \\
\hline
\end{tabular}

Table 7. Costs of windows for analysed variants, PLN/m².

\begin{tabular}{ccccccc}
\hline Variant & W-1 & W-2 & W-3 & W-4 & W-5 & W-6 \\
\hline & 860 & 330 & 710 & 903 & 416 & 767 \\
\hline
\end{tabular}




\section{Results and Discussion}

The study consists of the possible variants of the technical solutions for thermal insulation of the case study building and the different types of windows. The choice of the optimal solution from all acceptable solutions was made using the optimisation objectives presented in 2.2, comparing their values for any given variant to each other. Moreover, using the weighted sum method, the optimal solution was chosen for the BSC-A and BSC-B buildings, understood as separate buildings and as one building with different ways of air regulation intake.

\subsection{Primary Energy and Global Costs}

Following the European Directive provisions [42], in EU countries, the global cost method is applied to determine the requirements regarding the thermal protection of buildings. Based on the analyses presented by Basińska et al. [44-46], the optimal level (determined by the global cost method) corresponding with the minimum value of the global cost depends on the type of building, the technical solution applied and the assumed macro-economic parameters.

The possible technical solutions for the primary energy in the building have been indicated by the global cost method. Figure 2 presents the points for the BSC-A (colour) and BSC-B (grey) buildings with coordinates $\left(\mathrm{PE}_{\mathrm{H}+\mathrm{W}}, \mathrm{C}_{\mathrm{G}}\right)$, resulting from the combination of the building performance (solutions applied for the heat insulation of the walls and windows) split between the types of the applied insulation. All presented solutions refer to the heat energy supplied by means of a gas boiler. Figure 2 and the other figures in the study show the areas of discontinuity in the results, which are the effect of the initial assumptions regarding the thickness of the insulation (Table 3).

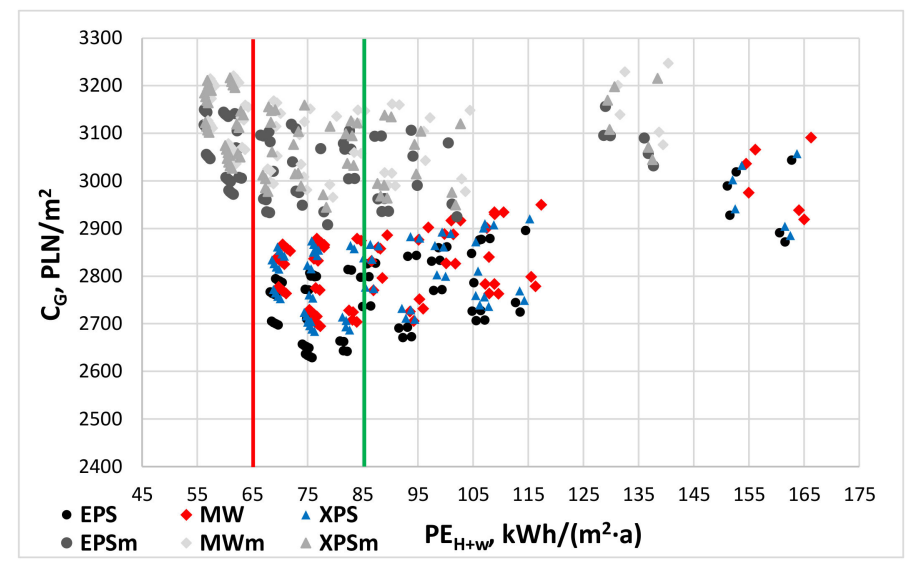

Figure 2. Global cost for analysed variants of building BSC-A (colour) BSC-B (grey).

Vertical lines in Figure 2 indicate the clear limits of primary energy ratio for the residential multi-family building defined according to the Polish national requirements (since 2017-green line and since 2021—red line) [47]. The use of mechanical ventilation in the building means that the value of a building's primary energy ratio is going down, but the global costs rise, due to the increase of investment costs related to such a solution.

There are some alternative solutions for a building equipped with natural and mechanical ventilation, as per the requirements WT 2017 - WT 2021 [47], but the energy optimum is achieved when the global cost value is higher. The BSC-A building with natural ventilation and the technical solution providing thermal transmittance for a window $\mathrm{U}_{\mathrm{w}}=1.352 \mathrm{~W} /\left(\mathrm{m}^{2} \cdot \mathrm{K}\right)$ and thermal transmittance for an external wall, $\mathrm{U}_{\mathrm{ex}}=0.11 \mathrm{~W} /\left(\mathrm{m}^{2} \cdot \mathrm{K}\right)(\mathrm{I}-9, \mathrm{~W} 2)$ is characterised by a comparable level of primary energy ratio value $P E_{\mathrm{H}+\mathrm{W}}=77 \mathrm{kWh} /\left(\mathrm{m}^{2} \cdot \mathrm{a}\right)$ as the BSC-B building equipped with mechanical ventilation, variant (I-5), (W-2), with the following characteristics: $\mathrm{U}_{\mathrm{w}}=1.018 \mathrm{~W} /\left(\mathrm{m}^{2} \cdot \mathrm{K}\right), \mathrm{U}_{\mathrm{ex}}=0.131 \mathrm{~W} /\left(\mathrm{m}^{2} \cdot \mathrm{K}\right)$, heat recovery $80 \%$. For these solutions, however, the value of the global cost is different and equals respectively to: BSC-A $-\mathrm{C}_{\mathrm{G}}=2629 \mathrm{PLN} / \mathrm{m}^{2}$ and BSC-B $-\mathrm{C}_{\mathrm{G}}=2908 \mathrm{PLN} / \mathrm{m}^{2}$. For buildings with 
natural ventilation, assuming the insulation with a significant thickness, the requirements of WT 2021 [47] are not fulfilled.

Some discrepancy of the primary energy ratio value can be noticed during the analysis of the building's energy characteristics (Figure 2), taking into consideration two technical solutions related to the way of air supply to the building with mechanical or natural ventilation. The obtained values are: $\mathrm{PE}_{\mathrm{H}+\mathrm{W}}$ from the range of $166.2-68.2 \mathrm{kWh} /\left(\mathrm{m}^{2} \cdot \mathrm{a}\right)$ to the range of $140.4-56.1 \mathrm{kWh} /\left(\mathrm{m}^{2} \cdot \mathrm{a}\right)\left(\mathrm{PE}_{\mathrm{H}+\mathrm{W}}=\right.$ $203.9 \mathrm{kWh} /\left(\mathrm{m}^{2} \cdot \mathrm{a}\right)$ for the base building).

Depending on the type of installed window, and the type of applied thermal insulation and its thickness, the primary energy ratio decreases in comparison with the base building. The smallest percentile change for BSC-A building in relation to the base building $\left(\mathrm{PE}_{\mathrm{H}+\mathrm{W}}=203.9 \mathrm{kWh} /\left(\mathrm{m}^{2} \cdot \mathrm{a}\right)\right)$ was obtained for the variant where mineral wool was $5 \mathrm{~cm}$ thick and the type of a window was $\mathrm{W}-1-18.5 \%$, while the largest was obtained for $30 \mathrm{~cm}$ of External Polystyrene (EPS) and window $\mathrm{W}-6-66.5 \%$. The difference between the percentile change $\mathrm{PE}_{\mathrm{H}+\mathrm{W}}$ for the applied thermo-insulation materials is insignificant and is average for all analysed windows in comparison to the EPS and thermal insulation thickness of $5 \mathrm{~cm}-1.69 \%$ for mineral wool (MW) and $0.46 \%$ for Extruded Polystyrene (XPS). With $30 \mathrm{~cm}$ thickness, the difference between the percentile change $\mathrm{PE}_{\mathrm{H}+\mathrm{W}}$ is lower $0.60 \%$ and $0.15 \%$, respectively. In the case of the BSC-B building, the effect of thermal insulation changes on the percentile change of primary energy index is less noticeable, assuming that the base building is equipped with a supply of exhaust ventilation. The smallest percentile change for the BSC-B building, in comparison to the base building equipped with mechanical ventilation $\left(\mathrm{PE}_{\mathrm{H}+\mathrm{W}}=180.6 \mathrm{kWh} /\left(\mathrm{m}^{2} \cdot \mathrm{a}\right)\right.$, was noticed for the variant with mineral wool of $5 \mathrm{~cm}$ in thickness and window type $\mathrm{W}-1-22.3 \%$, while the largest for EPS-30 $\mathrm{cm}$ thick and window $\mathrm{W}-6-68.9 \%$.

Another area of energy performance improvement results from the assumption that the component for hot domestic water preparation for each of the 216 variants was on average $P E_{W}=38.4 \mathrm{kWh} /\left(\mathrm{m}^{2} \cdot \mathrm{a}\right)$. For example, Figure 3 presents the relationship of the primary energy ratio for heating and ventilation purposes from the insulation thickness for all three types of insulation and two variants regarding windows solutions $\mathrm{W}-2\left(\mathrm{U}_{\mathrm{w}}=1.35 \mathrm{~W} /\left(\mathrm{m}^{2} \cdot \mathrm{K}\right)\right)$ and $\mathrm{W}-5\left(\mathrm{U}_{\mathrm{w}}=0.98 \mathrm{~W} /\left(\mathrm{m}^{2} \cdot \mathrm{K}\right)\right)$.

When taking into account only the heating and ventilation purposes, it might be noticed that the difference between the percentile of $\mathrm{PE}_{\mathrm{H}}$ change for the applied thermo-insulation materials is higher than when both heating and ventilation, as well as domestic hot water preparation, are considered. This is the average for all analysed windows in the BSC-A building in comparison to EPS and a thermal insulation of $5 \mathrm{~cm}$ in thickness-2.59\%, while for the mineral wool it is $0.71 \%$ for XPS. The difference between the percentile of $\mathrm{PE}_{\mathrm{H}}$ change is lower, and equals to $0.92 \%$ and $0.24 \%$, respectively, when the thickness is $30 \mathrm{~cm}$. For the BSC-B building, the following effect of the thermal insulation modification on the percentile change of primary energy ratio $\mathrm{PE}_{\mathrm{H}}$ has been noticed-for the variant with mineral wool of $5 \mathrm{~cm}$ in thickness and window type $\mathrm{W}-1-36.7 \%$, and the largest for EPS $30 \mathrm{~cm}$ in thickness and window type $\mathrm{W}-6-76.0 \%$. The average difference of percentages in comparison to EPS is as follows:

- thickness of the insulation made of mineral wool $5 \mathrm{~cm}-2.39 \%$

- thickness of thermal insulation with XPS $5 \mathrm{~cm}-0.65 \%$

- thickness of thermal insulation made of mineral wool $30 \mathrm{~cm}-0.70 \%$

- thickness of thermal insulation with XPS $30 \mathrm{~cm}-0.18 \%$

As a result of the above, levelling of the curves occurs above a thickness of $24 \mathrm{~cm}$ of additional thermal insulation, regardless of its type, as shown in Figure 3. The total thickness of thermal insulation for the analysed building is $36 \mathrm{~cm}$.

In order to picture the effect of the applied technical solutions, from a building's operation point of view, Figure 4 presents the primary energy ratio only for heating and ventilation purposes, as well as the global cost related to their application. 


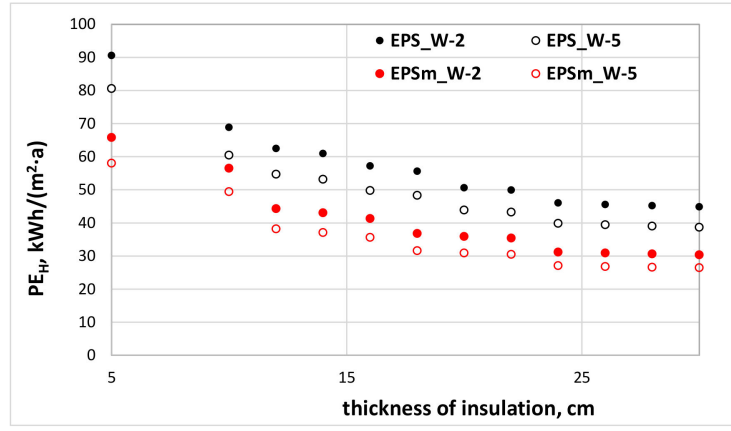

(a)

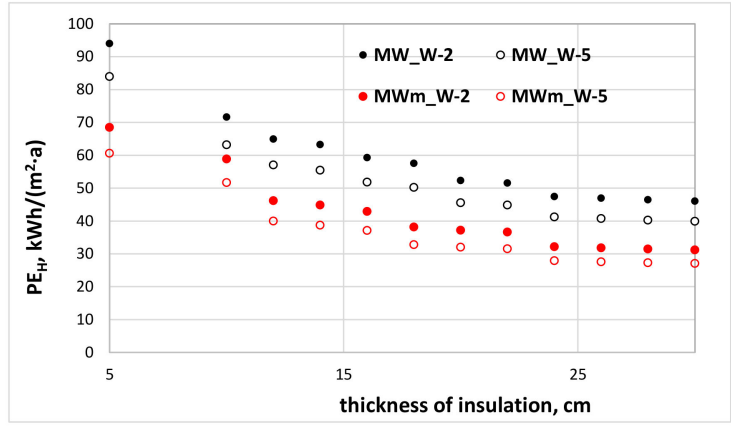

(b)

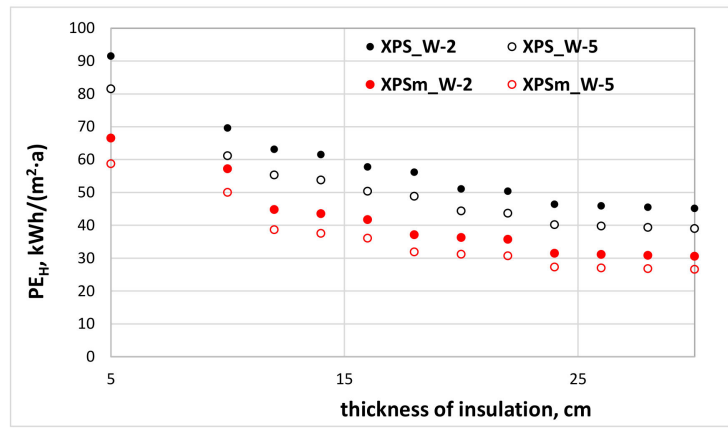

(c)

Figure 3. Primary energy ratio for heating and ventilation as a function of insulation thickness for (a) EPS, (b) MW, and (c) XPS for two variants of ventilation in the building.

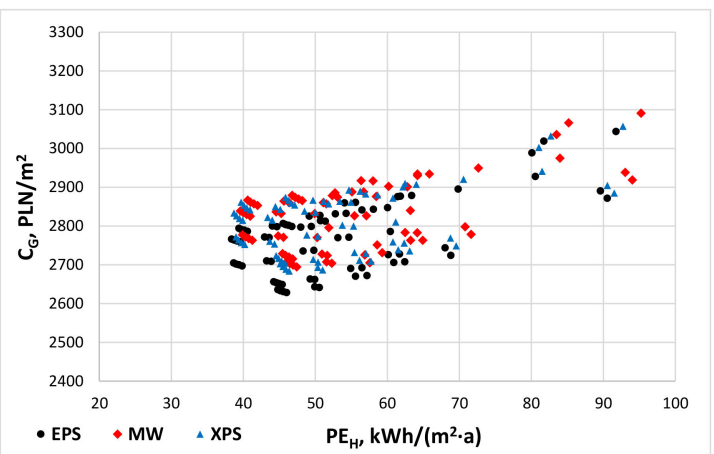

(a)

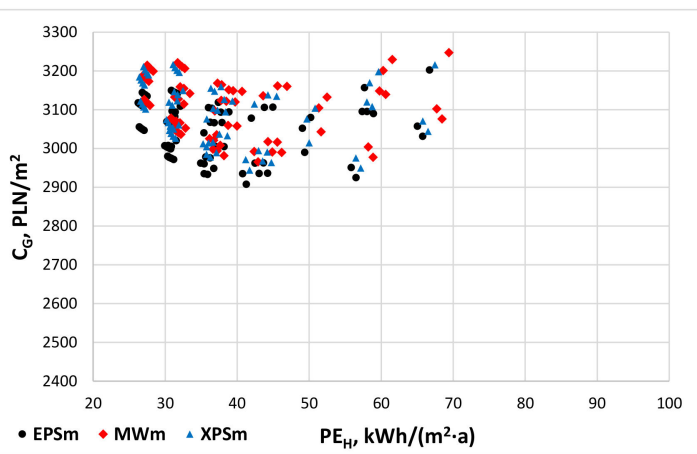

(b)

Figure 4. Energy optimum determined for the building by means of the global cost method (a) BSC-A, (b) BSC-B.

As presented on the diagrams prepared for BSC-A (Figure 4a) and BSC-B (Figure 4b) buildings, it is clear that the minimum value of the global cost is on the same level as in the case of analyses considering the energy for domestic hot water preparation. The primary energy ratio, however, changes for BSC-A building $\left(\mathrm{PE}_{\mathrm{H}}=46 \mathrm{kWh} /\left(\mathrm{m}^{2} \cdot \mathrm{a}\right)\right.$, i.e., the building with natural ventilation, additional insulation made of EPS $24 \mathrm{~cm}$ thick (total thickness of thermal insulation is $36 \mathrm{~cm}$ ) and plastic windows with traditional glazing (variant I-9, W-2). The same option was chosen for the building equipped with mechanical ventilation. As the thickness of thermal insulation increased, and due to the fact that the cost of this material is insignificant in terms of the total cost of re-insulation (for EPS of $5 \mathrm{~cm}$ thickness, it is $8.7 \%$, for $30 \mathrm{~cm}$ thickness, it increased to $35.3 \%$, and for XPS it was $18.2 \%$ and $55.5 \%$, respectively), the change of the global cost in comparison to the base building for the analysed variants was on average at 157.7 PLN/m² for the BSC-A building, and has varied depending on the applied 
thermo-insulating material and type of windows. The lowest average difference for all analysed thermo-insulation materials falls on window $\mathrm{W}-1$, made of aluminium with insulation made of mineral wool $\left(51.3 \mathrm{PLN} / \mathrm{m}^{2}\right)$, while the highest is for window $\mathrm{W}-2$, made of plastic, with insulation of EPS $\left(281.6 \mathrm{PLN} / \mathrm{m}^{2}\right)$. In the case of BSC-A, the lowest average was for window $\mathrm{W}-1$ and thermal insulation made of MW (-55.8 PLN $\left./ \mathrm{m}^{2}\right)$, while the highest was for window W-2 and EPS $\left(172.3 \mathrm{PLN} / \mathrm{m}^{2}\right)$. Figure 5 presents the comparison of the global cost as a function of the insulation thickness for windows W-1-W-4 for both analysed buildings with thermal insulation made of EPS. In the case of the BSC-A building, the global cost value is higher for window W-4 in relation to window W- 1 for $5 \mathrm{~cm}$-thick insulation, by only $24.9 \mathrm{PLN} / \mathrm{m}^{2}$. For the remaining thicknesses, the difference of the global cost value in relation to the value related to the base building varies from $66.6-163.0 \mathrm{PLN} / \mathrm{m}^{2}$ for window $\mathrm{W}-1$, and from 86.2-175.4 PLN $/ \mathrm{m}^{2}$ for window W-4. In the case of BSC-B building for $5 \mathrm{~cm}$, it is $112.5 \mathrm{PLN} / \mathrm{m}^{2}$. If the thickness of the thermal insulation is larger by an additional $24 \mathrm{~cm}$, the difference in the global cost is negative.

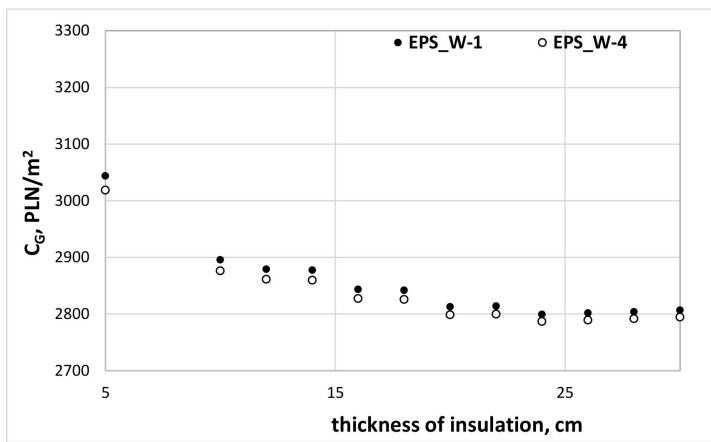

(a)

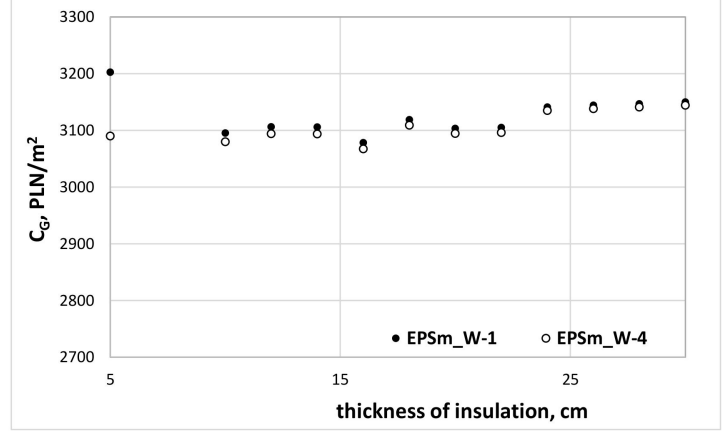

(b)

Figure 5. Global cost as a function of the thickness of thermo-insulation for windows W-1 and W-4 for the building (a) BSC-A and (b) BSC-B.

Additionally, in the economic analysis, using the global cost (Figure 5), the levelling of the curves is present for the thickness above $24 \mathrm{~cm}$, in the case of additional thermal insulation, regardless of its type (for the analysed building the total thickness of insulation is $36 \mathrm{~cm}$ ). The difference in the global cost goes down when the thickness of thermal insulation goes up. The improvement of glazing quality does not have a significant influence on the change of the global cost in the case of the analysed buildings.

\subsection{Primary Energy and Life Cycle Assessment}

If we assume LCA as the evaluation indicator, expressed as the reduction of $\mathrm{CO}_{2}$ emissions in relation to the base variant, the lowest impact on the environment, for both BSC-A and BSC-B, is for the variant where the additional $28 \mathrm{~cm}$ thick MW was applied with the timber window W- 6 with glazing U-factor, $\mathrm{U}_{\mathrm{g}}=0.6 \mathrm{~W} /\left(\mathrm{m}^{2} \cdot \mathrm{K}\right)$. In BSC-A building; however, this corresponds with a global cost value at a level of $\mathrm{C}_{\mathrm{G}}=2839.0 \mathrm{PLN} / \mathrm{m}^{2}$ when $\mathrm{PE} \mathrm{H}_{\mathrm{H}+\mathrm{W}}=69.4 \mathrm{kWh} /\left(\mathrm{m}^{2} \cdot \mathrm{a}\right)$, and for BSC-B building, $\mathrm{C}_{\mathrm{G}}$ $=3188.6 \mathrm{PLN} / \mathrm{m}^{2}$ when $\mathrm{PE}_{\mathrm{H}+\mathrm{W}}=56.8 \mathrm{kWh} /\left(\mathrm{m}^{2} \cdot \mathrm{a}\right)$. Assuming that $\mathrm{CO}_{2}$ emission reduction is only related to operational energy (omitting the stages of production and exchange), the variant with the lowest impact on the environment, for BSC-A and BSC-B buildings, is the variant with the additional $28 \mathrm{~cm}$ of EPS thickness and the timber window W-6 with glazing $\mathrm{U}$-factor, $\mathrm{U}_{\mathrm{g}}=0.6 \mathrm{~W} /\left(\mathrm{m}^{2} \cdot \mathrm{K}\right)$, which corresponds to the global cost value equal to $\mathrm{C}_{\mathrm{G}}=2826.5 \mathrm{PLN} / \mathrm{m}^{2}$ with $\mathrm{PE}_{\mathrm{H}+\mathrm{W}}=68.9 \mathrm{kWh} /\left(\mathrm{m}^{2} \cdot \mathrm{a}\right)$ for the BSC-A building and $\mathrm{C}_{\mathrm{G}}=3176.9 \mathrm{PLN}$ with $\mathrm{PE}+\mathrm{H}=56.5 \mathrm{kWh} /\left(\mathrm{m}^{2} \cdot \mathrm{a}\right)$ for the BSC-B building. Taking into account only the production and exchange stages, however, the highest emissions of $\mathrm{CO}_{2}$ are characteristic of the variant with the additional insulation of $28 \mathrm{~cm}$ in thickness-in this case XPS—and the aluminium window $\mathrm{W}-4$ with glazing $\mathrm{U}$-factor, $\mathrm{U}_{\mathrm{g}}=0.6 \mathrm{~W} /\left(\mathrm{m}^{2} \cdot \mathrm{K}\right)$. 
Therefore, the additional energy and economic disbursals during the production stage of the materials and elements that need to be replaced are insignificant in comparison to the expected savings from thermo-modernisation, as the energy demand will decrease.

For example, Figure 6 presents the variability of LCA for window W-1 in BSC-A and BSC-B buildings, as the reduction of $\mathrm{CO}_{2}$ emissions depends on the insulation thickness and the thermo-insulation material. The total reduction of $\mathrm{CO}_{2}$ emissions equal to $1170 \mathrm{kgCO} / \mathrm{m}^{2}$ will be achieved with an insulation thickness of $28 \mathrm{~cm}$ for BSC-A variant, when applying mineral wool with thermal conductivity $\lambda=0.039 \mathrm{~W} /(\mathrm{m} \cdot \mathrm{K})$ and $\mathrm{CO}_{2}$ emissions during the production and exchange stages are at the level of $65 \mathrm{kgCO}_{2} / \mathrm{m}^{2}$. Similar reciprocities can be obtained for solution BSC-B, in the case of mineral wool, with total reduction of $\mathrm{CO}_{2}$ emissions at $1027 \mathrm{kgCO}_{2} / \mathrm{m}^{2}$, while for EPS, this is $1024 \mathrm{kgCO} / \mathrm{m}^{2}$.

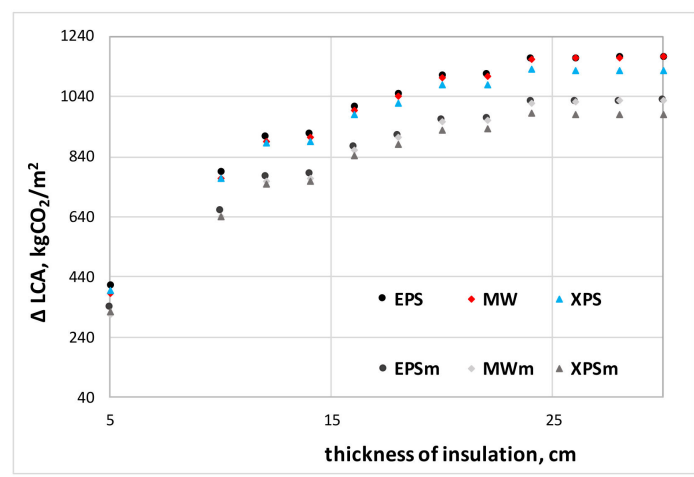

Figure 6. Reduction of $\mathrm{CO}_{2}$ emissions for the analysed variants of BSC-A (colour) and BSC-B (grey) buildings for different thermo-insulation materials.

The above example shows that the solutions characterised by the lower emissions of $\mathrm{CO}_{2}$ on the production stage can be balanced with the solutions characterised by higher emissions of $\mathrm{CO}_{2}$ in the production stage and higher energy savings at the same time.

\subsection{Multi-Objective Analysis}

The different possible solutions can be indicated using the separately assumed criteria. The conducted analysis proves that depending on the evaluation criterion, a different optimum value can be obtained. In the case of the global cost, this can be the minimisation of its cost or the maximisation of the difference in the variant's global cost in comparison to the reference variant. Figure 7 presents the relationships among the analysed criteria for BSC-A and BSC-B buildings.

The diagrams (Figure 7) present the shift of $\mathrm{PE}_{\mathrm{H}}$ and $\triangle \mathrm{LCA}$ into lower values for the BSC-B building equipped with mechanical ventilation. A strong linear decreasing relation between $\mathrm{PE}_{\mathrm{H}}$ and $\triangle \mathrm{LCA}$ is presented and the dependency of $\Delta \mathrm{C}_{\mathrm{G}}$ from $\triangle \mathrm{LCA}$ but only for the building with natural ventilation. When the primary energy ratio rises for heating and ventilation, the $\mathrm{CO}_{2}$ emissions decrease. In the case of the relationship between $\Delta \mathrm{C}_{\mathrm{G}}$ and $\Delta \mathrm{LCA}$ for the BCS-A building with natural ventilation, the linear formation of points for three groups considering the analysed three types of windows can be noticed. The highest value of $\triangle \mathrm{LCA}$ (expressed as a reduction of $\mathrm{CO}_{2}$ emissions) in the given variant of thermo-insulation was noticed for the window in the timber frame, and the lowest for the aluminium frame window. In the case of the relationship between $\Delta \mathrm{C}_{\mathrm{G}}$ and $\mathrm{PE}_{\mathrm{H}}$, the points form a parabola with a negative slope. This is quite clear for the BSC-B building. Starting from the primary energy ratio value $\mathrm{PE}_{\mathrm{H}}=41 \mathrm{kWh} /\left(\mathrm{m}^{2} \cdot \mathrm{a}\right)$, with the improvement of the thermal performance of the building (decreasing of $\mathrm{EP}_{\mathrm{H}}$ ), the global cost calculated for the building's life cycle decreases in comparison to the global cost value for the base building. The clearer relationships for the BCS-B building are the result of the fact that all analyses assume that the base building has natural ventilation. 

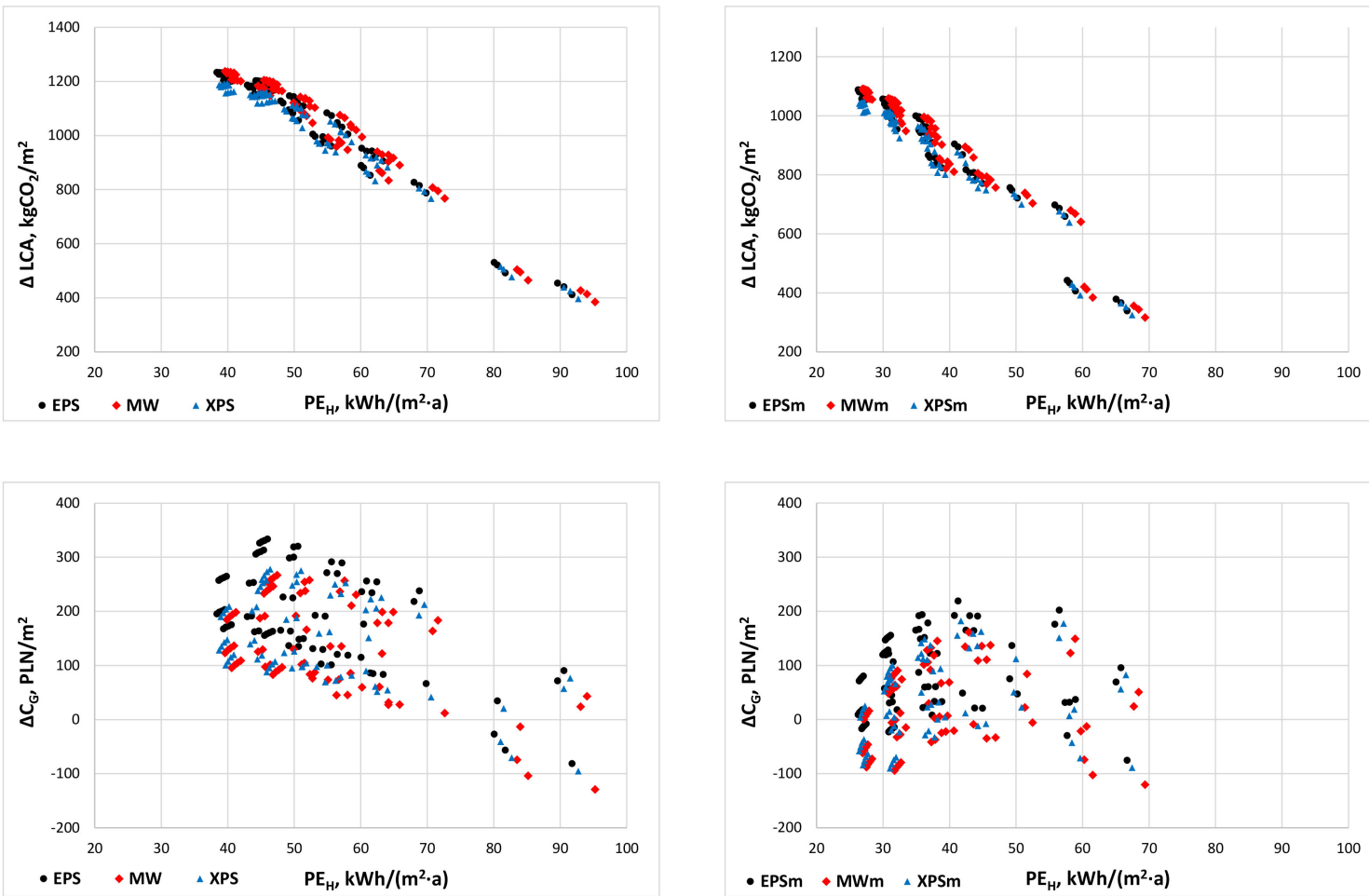

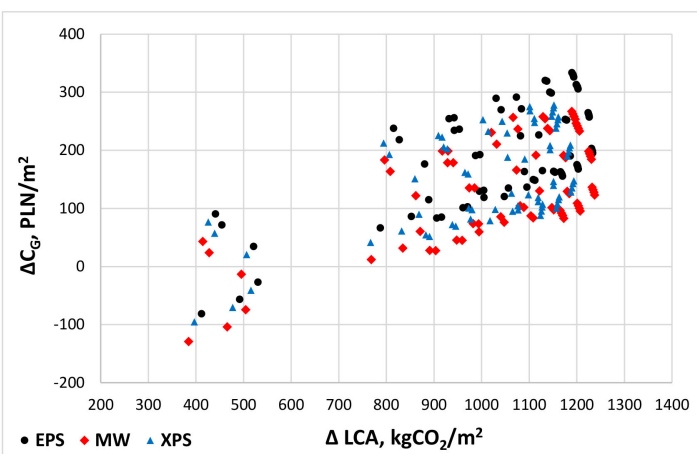

(a)

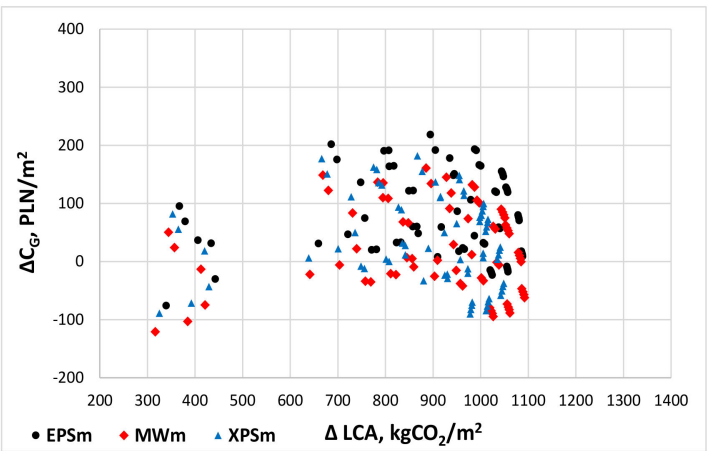

(b)

Figure 7. Relationship between the analysed evaluation criteria for building (a) BSC-A and (b) BSC-B for different thermo-insulation materials.

In order to provide the overall evaluation of the proposed solutions, multi-objective analysis has been applied. This allows choosing the technical solution, taking into consideration the economy, energy and environmental parameters. The algorithms presented in Section 2 have been applied. In order to determine the weights of the individual criteria, the method presented by Mróz [48] was used. This method is based on the statistical calculation of the deviation factor defined as the ratio of standard deviation of criterion $\rightarrow x$ and its mean value.

Table 8 presents the list of weights for the criteria of the analysed buildings.

Table 8. Weight factor for buildings BSC-A and BSC-B and their variants.

\begin{tabular}{ccccc}
\hline Criteria & $\mathbf{P E}_{\mathbf{H}+\mathbf{W}}$ & $\boldsymbol{\Delta} \mathbf{L C A}$ & $\mathbf{C}_{\mathrm{G}}$ & $\Delta \mathbf{C}_{\mathbf{G}}$ \\
\hline BSC-A & 0.27 & 0.21 & 0.03 & 0.49 \\
BSC-B & 0.22 & 0.17 & 0.02 & 0.59 \\
BSC-A + BSC-B & 0.16 & 0.41 & 0.03 & 0.39 \\
\hline
\end{tabular}


Table 8 shows that the criterion with the highest weight, considering four criteria, is the global cost increase criterion in relation to the base building (variant I-0). The criteria with comparable weights are the primary energy values $\mathrm{PE}_{\mathrm{H}+\mathrm{W}}$ and the reduction of $\mathrm{CO}_{2}$ emissions $-\Delta \mathrm{LCA}$. The low weight of the global cost criterion is noteworthy, which, in the energy optimum analyses, is one of the two main criteria, next to the $\mathrm{PE}_{\mathrm{H}+\mathrm{W}}$ ratio. Considering all four criteria together for both types of buildings, the optimal solution is to apply mechanical ventilation with heat recovery with efficiency of $90 \%$, thermal insulation of $30 \mathrm{~cm}$ in thickness made of MW and windows made of PVC with W-5 characteristics $\mathrm{PE}_{\mathrm{H}+\mathrm{W}}=56.9 \mathrm{kWh} /\left(\mathrm{m}^{2} \mathrm{a}\right)$ and $\mathrm{C}_{\mathrm{G}}=3126.5 \mathrm{PLN} / \mathrm{m}^{2}$.

Considering only three initial criteria, the most important is $\mathrm{PE}_{\mathrm{H}+\mathrm{W}}$, with a mean weight of 0.53 , $\triangle \mathrm{LCA}-0.41$ and $\mathrm{C}_{\mathrm{G}}-0.07$ for each of the analysed buildings. The best technical solution for the BSC-A building proved to be the variant of additional thermo-insulation Ib-12 (XPS, an additional thickness of $30 \mathrm{~cm}$ ) with window $\mathrm{W}-6$. The searched solution is the technical solution for which $\mathrm{EP}_{\mathrm{H}+\mathrm{W}}$ $=68.5 \mathrm{kWh} /\left(\mathrm{m}^{2} \cdot \mathrm{a}\right)$ and $\mathrm{C}_{\mathrm{G}}=2834 \mathrm{PLN} / \mathrm{m}^{2}$. For the BSC-B building, this is $\mathrm{PE}+\mathrm{H}+\mathrm{W}=60.0 \mathrm{kWh} /\left(\mathrm{m}^{2} \cdot \mathrm{a}\right)$ and $\mathrm{C}_{\mathrm{G}}=3074 \mathrm{PLN} / \mathrm{m}^{2}$ (Ib-12, W-3). Analysing jointly the proposed solutions for buildings BSC-A and BSC-B, and taking into consideration only three criteria for the evaluation of the optimal solution gives the same result as the four criteria analysis.

It is clear from the above that improvement in the thermal performance of buildings should be focused on their ventilation systems.

Using the method described in the study, finding the appropriate solution is straightforward and can support the design and decision-making processes leading to the best choice.

\section{Conclusions}

The multi-objective method has been used in this study in order to choose feasible technical solutions that would improve the energy performance of buildings, which have been subject to thermal improvement. A total of 216 packages of possible solutions regarding additional thermal insulation and window replacements have been analysed for each of two buildings, one with natural ventilation (BSC-A) and another with mechanical supply-exhaust ventilation (BSC-B). The issue of optimisation was solved by means of the weighted sum method. The most significant conclusions from multi-criteria optimisation are summarised as follows:

- the proposed multi-objective optimisation method allowed for a choice of technical solutions regarding a building's thermo-insulation assuming the criteria recognised as most important.

- the choice of criteria is not binding, but it results from rational energy- and economy-related assumptions used in the process of optimisation.

- each time a given criterion was chosen, the relationship between the criteria should be limited.

- depending on the number of assumed criteria, their weights change; however, this does not affect the obtained optimal solutions.

- the proposed model might be used not only for the evaluation of structural and architectural solutions regarding the external walls of the building but also for the evaluation of HVAC systems.

- Based on the conducted analyses, it can be stated that:

- $\quad$ in order to achieve the energy standard WT 2021 [47], the application of natural ventilation is impossible even if the thermal insulation of the building walls is high (thickness of insulation of the external wall above $30 \mathrm{~cm}$ ).

- fulfilling the requirements of the thermal protection of buildings WT 2021 [47] is possible only if mechanical ventilation is applied in the building including high-performance heat recovery, above $80 \%$, and the thickness of insulation exceeds $32 \mathrm{~cm}$.

- $\quad$ as per WT 2017 and WT 2021 [47], there are some alternative solutions between buildings with natural ventilation and buildings with mechanical ventilation with heat recovery, characterised by the same primary energy ratio and a different level of global cost. 
- the best technical solution for buildings proved to be the variant of additional thermo-insulation $\mathrm{Ib}-12$ (XPS, additional thickness of $30 \mathrm{~cm}$ ) with wood window $\mathrm{W}-6\left(\mathrm{Ug}=0.6 \mathrm{~W} /\left(\mathrm{m}^{2} \cdot \mathrm{a}\right)\right)$ for BSC-A and $\mathrm{W}-3\left(\mathrm{Ug}=1.1 \mathrm{~W} /\left(\mathrm{m}^{2} \cdot \mathrm{a}\right)\right)$ for BSC-B.

- the use of better glazing in windows, given its higher cost, does not result in a significant change in value of global cost.

- the additional energy and environmental input during the production of materials and refurbishment elements are insignificant in comparison to the savings as a result of thermo-modernisation, due to the high decrease of energy demand.

- the use of insulation (MW, EPS, XPS) with thickness above $36 \mathrm{~cm}$ does not automatically result in significant energy and economic savings.

- $\quad$ in order to achieve the parameters of comfort and quality of air in buildings with low energy consumption, an increase of energy consumption for domestic hot water preparation can be noted.

- the reduction of $\mathrm{CO}_{2}$ emissions associated with energy savings during the operation of a building as a result of thermo-modernisation is much larger than the $\mathrm{CO}_{2}$ emissions associated with the production of materials, components and their replacement. Therefore, the LCA for buildings where large energy savings from thermo-modernisation strategies can be achieved could likely reduce operational energy use evaluation.

Author Contributions: Conceptualisation, M.B., D.K. and H.K.; methodology, M.B. and D.K.; formal analysis, M.B., D.K. and H.K.; investigation, M.B., D.K. and H.K.; resources, D.K.; data curation, M.B.; writing-original draft preparation, M.B. and D.K.; writing-review and editing, M.B. and D.K.; visualisation, M.B. and D.K.; supervision, H.K. All authors have read and agreed to the published version of the manuscript.

Funding: This research received no external funding.

Conflicts of Interest: The authors declare no conflict of interest.

$\begin{array}{ll}\text { Abbreviations } \\ \text { ACH } & \text { air exchange } \\ \text { ANN } & \text { artificial neural network } \\ \text { BSC } & \text { building shape coefficient } \\ \text { Cr } & \text { criteria } \\ \text { EPBD } & \text { Energy Performance of Building Directive } \\ \text { EPD } & \text { environmental product declaration } \\ \text { EPS } & \text { external polystyrene } \\ \text { EUAC } & \text { equivalent uniform annual cost } \\ \text { GA } & \text { genetic algorithm } \\ \text { HVAC } & \text { heating, ventilation, air-conditioning } \\ \text { LCA } & \text { life cycle assessment } \\ \text { LCC } & \text { life cycle cost } \\ \text { LCCF } & \text { life cycle carbon footprint } \\ \text { MOEA } & \text { multi-objective evolutionary algorithms } \\ \text { MOGA } & \text { multi objective genetic algorithms } \\ \text { MOO } & \text { multi-objective optimisation } \\ \text { WSM } & \text { weighted sum model } \\ \text { MW } & \text { mineral wool } \\ \text { NPV } & \text { Net Present Value } \\ \text { NSGA-II } & \text { distance sorting genetic algorithm } \\ \text { nZEB } & \text { zero energy building } \\ \text { TEC } & \text { total energy consumption } \\ \text { WIBOR } & \text { Warsaw Interbank Offered Rate } \\ \text { WT } & \text { the technical conditions for the buildings } \\ \text { XPS } & \text { extruded polystyrene }\end{array}$




\section{Nomenclature}

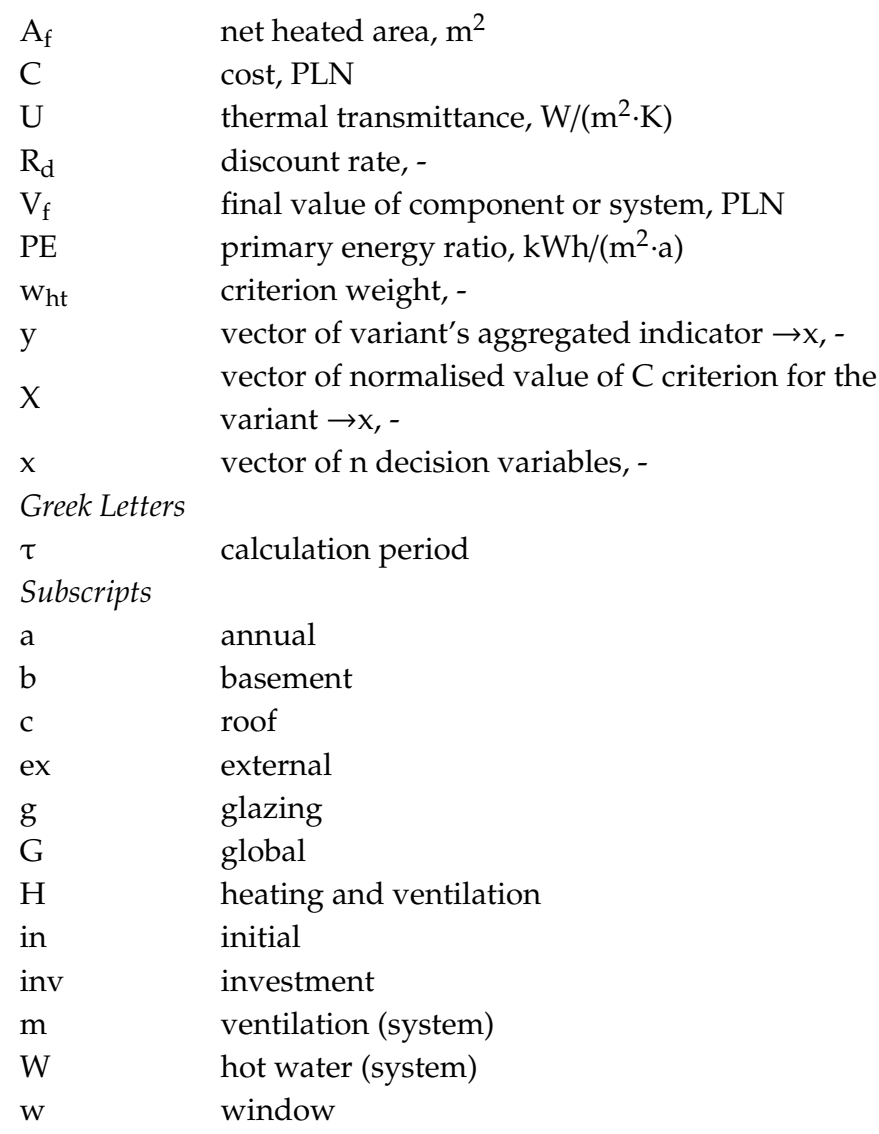

\section{References}

1. EU Commission and Parliament. Directive 2018/844 of the European Parliament and the Council of the 30 May 2018 Amending Directive 2010/31/EU on the Energy Performance of Buildings and Directive 2012/27/EU on Energy Efficiency. Off. J. Eur. Union 2018, 156, 75-91.

2. Salata, F.; Ciancio, V.; Dell'Olmo, J.; Golasi, I.; Palusci, O. Effects of local conditions on the multi-variable and multi-objective energy optimization of residential buildings using genetic algorithms. Appl. Energy 2020, 260, 114289. [CrossRef]

3. EU Commission. H2020 DRIVE O Project. Available online: https://www.drive0.eu (accessed on 11 March 2020).

4. EU Commission. H2020 Step UP project. Available online: https://www.stepup-project.eu/ (accessed on 11 March 2020).

5. Tian, Z.C.; Chen, W.Q.; Tang, P.; Wang, J.; Shi, X. Building energy optimization tools and their applicability in architectural conceptual design stage. Energy Procedia 2015, 78, 2572-2577. [CrossRef]

6. Nguyen, A.-T.; Reiter, S.; Rigo, P. A review on simulation-based optimization methods applied to building performance analysis. Appl. Energy 2014, 113, 1043-1058. [CrossRef]

7. Ascione, F.; Bianco, N.; Mauro, G.M.; Vanoli, G.P. A new comprehensive framework for the multi-objective optimization of building energy design: Harlequin. Appl. Energy 2019, 241, 331-361. [CrossRef]

8. Bolattürk, A. Optimum insulation thicknesses for building walls with respect to cooling and heating degree-hours in the warmest zone of Turkey. Build. Environ. 2008, 43, 1055-1064. [CrossRef]

9. Flores-Colen, I.; De Brito, J. A systematic approach for maintenance budgeting of buildings facades based on predictive and preventive strategies. Constr. Build. Mater. 2010, 24, 1718-1729. [CrossRef]

10. Gasparella, A.; Pernigotto, G.; Cappelletti, F.; Romagnoni, P.; Baggio, P. Analysis and modelling of window and glazing systems energy performance for a well insulated residential building. Energy Build. 2011, 43, 1030-1037. [CrossRef] 
11. Ruiz, M.C.; Romero, E. Energy saving in the conventional design of a Spanish house using thermal simulation. Energy Build. 2011, 43, 3226-3235. [CrossRef]

12. Yu, J.; Yang, C.; Tian, L. Low-energy envelop design of residential building in hot summer and cold winter zone in China. Energy Build. 2008, 40, 1536-1546. [CrossRef]

13. Asadi, E.; Gameiro da Silva, M.; Henggeler Antunes, C.; Dias, L.; Glicksman, L. Multi-objective optimization for building retrofit: A model using genetic algorithm and artificial neural network and an application. Energy Build. 2014, 81, 444-456. [CrossRef]

14. Basińska, M. The use of multi-criteria optimization to choose solutions for energy-efficient buildings. Bull. Pol. Acad. Sci. Tech. 2017, 65, 815-826. [CrossRef]

15. Fan, Y.; Xia, X. A multi-objective optimization model for energy-efficiency building envelope retrofitting plan with rooftop PV system installation and maintenance. Appl. Energy 2017, 189, 327-335. [CrossRef]

16. Yusoff, Y.; Ngadiman, M.S.; Zain, A.M. Overview of NSGA-II for optimizing machining process parameters. Procedia Eng. 2011, 15, 3978-3983. [CrossRef]

17. Yu, W.; Li, B.; Jia, H.; Zhang, M.; Wang, D. Application of multi-objective genetic algorithm to optimize energy efficiency and thermal comfort in building design. Energy Build. 2015, 88, 135-143. [CrossRef]

18. Li, K.; Pan, L.; Xue, W.; Jiang, H.; Mao, H. Multi-Objective Optimization for Energy Performance Improvement of Residential Buildings: A Comparative Study. Energies 2017, 10, 245. [CrossRef]

19. Abdallah, M.; El-Rayes, K. Optimizing the selection of building upgrade measures to minimize the operational negative environmental impacts of existing buildings. Build. Environ. 2015, 84, 32-43. [CrossRef]

20. Yang, C.; Li, H.; Rezgui, Y.; Petri, I.; Yuce, B. High throughput computing based distributed genetic algorithm for building energy consumption optimization. Energy Build. 2014, 76, 92-101. [CrossRef]

21. Penna, P.; Prada, A.; Cappelletti, F.; Gasparella, A. Multi-objectives optimization of Energy Efficiency Measures in existing buildings. Energy Build. 2015, 95, 57-69. [CrossRef]

22. Castelli, M.; Trujillo, L.; Vanneschi, L.; Popovič, A. Prediction of energy performance of residential buildings: A genetic programming approach. Energy Build. 2015, 102, 67-74. [CrossRef]

23. Palonen, M.; Hasan, A.; Siren, K. A Genetic Algorithm for Optimization of Building Envelope and Hvac System Parameters. In Proceedings of the 11th International IBPSA Building Simulation, Glasgow, Scotland, 27-30 July 2009.

24. Hamdy, M.; Mauro, G.M. Multi-Objective Optimization of Building Energy Design to Reconcile Collective and Private Perspectives: CO2-eq vs. Discounted Payback Time. Energies 2020, 10, 1016. [CrossRef]

25. Brunelli, C.; Castellani, F.; Garinei, A.; Biondi, L.; Marconi, M. A Procedure to Perform Multi-Objective Optimization for Sustainable Design of Buildings. Energies 2016, 9, 915. [CrossRef]

26. Szwartz, Y.; Raslan, R.; Mumovic, D. Implementing multi objective genetic algorithm for life cycle carbon footprint and life cycle cost minimalization: A building refurbishment case study. Energy 2016, 97, 58-68. [CrossRef]

27. Sharif, S.A.; Hammad, A. Developing surrogate ANN for selecting near-optimal building energy renovation methods considering energy consumption. LCC and LCA. J. Build. Eng. 2019, 25, 100790. [CrossRef]

28. Grygierek, K.; Ferdyn-Grygierek, J. Multi-Objective optimization of Envelope Building with Natural Ventilation. Energies 2019, 11, 1383. [CrossRef]

29. Bre, F.; Santos Silva, A.; Ghisi, E.; Fachinotti, V. Residential building design optimisation using sensitivity analysis and genetic algorithm. Energy Build. 2016, 853-866. [CrossRef]

30. Polish Committee for Standardization. Polish Standard PN-EN ISO 13790:2009. In Energy Performance of Buildings. Calculation of Energy use for Space Heating and Cooling; Polish Committee for Standardization: Warsaw, Poland, 2009.

31. Polish Ministry of Economic Development. Home Page. Available online: https://dane.gov.pl/dataset/ 797, typowe-lata-meteorologiczne-i-statystyczne-dane-klimatyczne-dla-obszaru-polski-do-obliczenenergetycznych-budynkow (accessed on 25 December 2019).

32. Basińska, M.; Koczyk, H.; Szczechowiak, E. Sensitivity analysis of determining the optimum energy for residential buildings in Polish conditions. Energy Build. 2015, 107, 307-318. [CrossRef]

33. Polish Committee for Standardization. Polish Standard PN-EN 15804+A1:2014-04 In Sustainability of construction works-Environmental product declarations - Core rules for the product category of construction products; Polish Committee for Standardization: Warsaw, Poland, 2014. 
34. Oregi, X.; Hernandez, P.; Hernandez, R. Analysis of life-cycle boundaries for environmental and economic assessment of building energy refurbishment project. Energy Build. 2017, 136, 12-25. [CrossRef]

35. Sartori, I.; Hestnes, A.G. Energy use in life cycle of conventional and low energy buildings: A review article. Energy Build. 2007, 39, 249-257. [CrossRef]

36. Ecoinvent. Database. Available online: https://www.ecoinvent.org (accessed on 5 October 2019).

37. Saint-Gobain Glass. Environmental Product Declaration. SGG CLIMAPLUS. Available online: https: //gryphon4.environdec.com/system/data/files/6/12121/epd932\%20Saint-Gobain\%20Climaplus\%20V.02.pdf (accessed on 20 October 2019).

38. Saint-Gobain Glass. Declaration Environnemental et Sanitarie. SGG CLIMATOP. Available online: https://gryphon4.environdec.com/system/data/files/6/12124/S-P-00933\%20EPD\%20Saint-Gobain\% 20Climatop.pdf (accessed on 20 October 2019).

39. Environmental Product Declaration; Synthos XPS Insulation Board. Available online: http://www. greenbooklive.com/filelibrary/EN_15804/EPD/EN-EPD-0058.pdf (accessed on 20 October 2019).

40. Environmental Product Declaration; Isover Glass Wool. Available online: https://www.itb.pl/g/f/2031,epdisover-glass-wool.pdf. (accessed on 20 October 2019).

41. Environmental Product Declaration; Expanded Polystyrene (EPS). Available online: https://eumeps. construction/sustainability/environmental-impact. (accessed on 20 October 2019).

42. EU Commission and Parliament. Directive 2010/31/EU of the European Parliament and the Council of the European Union of the 19 May 2010 on the Energy Performance of Buildings. Off. J. Eur. Union 2010, 153, 13-35.

43. Polish Committee for Standardization. Polish Standard PN-EN 15459:2008. In Energy performance of buildings. Economic evaluation procedure for energy systems in buildings; Polish Committee for Standardization: Warsaw, Poland, 2008.

44. Geryło, R. The Economic Optimum of Energy Requirements for Buildings in Poland. Proceedings of 61th Scientific Conference of the Civil and Water Engineering of the Polish Academy of Science (PAN) and of the Science Committee PZITB, Bydgoszcz-Krynica, Poland, 20-25 September 2015; pp. 231-240, Problem part: Energy-saving construction in Poland-Current State and Perspectives.

45. Hamdy, M.; Hasan, A.; Siren, K. A multi-stage optimization method for cost-optimal and nearly-zero-energy building solutions in line with the EPBD. Recast 2010. Energy Build. 2013, 56, 189-203. [CrossRef]

46. Koczyk, H.; Basińska, M. Energy-Economic Optimum of Installation Solutions for Energy Efficient Buildings. Proceedings of 61th Scientific Conference of the Civil and Water Engineering of the Polish Academy of Science (PAN) and of the Science Committee PZITB, Bydgoszcz-Krynica, Poland, 20-25 September 2015; pp. 241-252, Problem part: Energy-saving construction in Poland-Current State and Perspectives.

47. Polish Ministry of Infrastructure. Regulation of Minister of Infrastructure of 12 April 2002 on the Technical Condition That Should Be Met by Buildings and Their Location; > Journal of Laws of the Republic of Poland no 75, item 690 (with recast); Polish Ministry of Infrastructure: Warsaw, Poland, 2002; Available online: http://prawo.sejm.gov.pl/isap.nsf/DocDetails.xsp?id=WDU20190001065 (accessed on 25 December 2019). (In Polish)

48. Mróz, T.M. Energy Management in Built Environment. Tools and Evaluation Procedures; Poznań University of Technology: Poznań, Poland, 2013.

(C) 2020 by the authors. Licensee MDPI, Basel, Switzerland. This article is an open access article distributed under the terms and conditions of the Creative Commons Attribution (CC BY) license (http://creativecommons.org/licenses/by/4.0/). 